\title{
Pengaruh suplementasi glisin terhadap kadar serum transferrin receptor (stfr) dan kadar hemoglobin (hb)
}

\section{Dian Ayu $\mathbf{Z}^{1}$}

\begin{abstract}
Background: Iron deficiency anemia (IDA) is still become a health problem in female adolescents. Iron supplementation only as a treatment for IDA still can not reach an optimum results. With that result, there was necessary to developing a strategy for iron supplementation, once treatment with glicyne.

Objective: to describe the effect of glycine supplementation on serum transferrin receptor (sTfR) levels and Hemoglobin (Hb) levels in female teenagers with IDA.

Methods: This study was quasi experimental, pre post test control group design. The population was female teenagers age $12-$ 18 years, $\mathrm{Hb}<12 \mathrm{mg} / \mathrm{dl}$, sTfR > 18,4 nmol/L, involving 50 subjects, devided into two groups. The first group was experiment group that given the supplement of $60 \mathrm{mg}$ iron and $1 \mathrm{gr}$ glycine a day for 4 weeks. The second group was control group that given the supplement of only $60 \mathrm{mg}$ iron a day for 4 weeks. The data were analyzed with bivariate test, paired t test, independent t test.

Results: There was significantly lower decreased of sTfR levels in treatment group 6,923 $\pm 10,13$ nmol/L than control group $0.809,65 \pm 9,076 \mathrm{nmol} / \mathrm{L}$ with $\mathrm{p}=0,008$, and significant increased of Hb levels in both treatment group 0,79 $\pm 1,15 \mathrm{mg} / \mathrm{dl}$ and control group 0,22 $\pm 0,48 \mathrm{mg} / \mathrm{dl}$ with $\mathrm{p}=0,03$.

Conclusion: Glycine supplementation for 4 weeks decreased sTfR levels in female teenagers with IDA before controlled by vitamin c intake $(p=0,04)$ and after controlled by vitamin $c$ intake variable $(p=0,002)$ and increased Hb levels before controlled by vitamin $c$ intake $(p=0,02)$ and after controlled by vitamin c intake variable $(p=0,04)$.
\end{abstract}

Keywords: glycine; iron; iron deficiency anemia; sTfR; Hb; female teenagers.

\begin{abstract}
ABSTRAK
Latar Belakang: Anemia defisiensi besi $(A D B)$ masih menjadi permasalahan kesehatan bagi remaja putri. Suplementasi besi sebagai upaya penanggulangan ADB belum menunjukkan hasil yang optimal, sehingga diperlukan pengembangan suplementasi besi, salah satunya dengan glisin.Tujuan: Mendiskripsikan pengaruh suplementasi glisin terhadap kadar sTfR dan kadar Hb pada remaja putri anemia defisiensi besi yang disuplementasi besi. Metoda: Penelitian ini merupakan penelitian quasi experiment dengan pre-post test control group design. Populasi adalah remaja putri usia $12-18$ tahun, Hb $\langle 12 \mathrm{mg} / \mathrm{dl}$, sTfR $>$ 18,4 nmol/L, melibatkan 50 remaja putri yang dibagi menjadi dua kelompok yaitu kelompok perlakuan mendapat suplementasi besi 60 mg dan 1 gr glisin tiap hari selama 4 minggu, dan kelompok kontrol mendapat suplementasi besi 60 mg saja tiap hari selama 4 minggu. Data yang diteliti meliputi asupan zat gizi, kadar sTfR, kadar Hb. Data dianalisis menggunakan uji bivariat, paired $t$ test, independent $t$ test. Hasil: Terjadi penurunan kadar sTfR pada kelompok perlakuan 6,923 $\pm 10,13$ yang berbeda

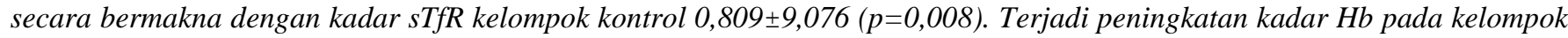
perlakuan 0,79 $\pm 1,15$ yang berbeda secara bermakna dengan peningkatan kadar Hb kelompok kontrol 0,22 $\pm 0,48$ ( $p=0,03)$. Simpulan: Suplementasi glisin menaikkan kadar Hb remaja putri penderita anemia defisiensi besi (ADB) sebelum dikontrol dengan variabel asupan vitamin $C(p=0,04)$ dan sesudah dikontrol asupan vitamin $C(p=0,002)$. Suplementasi glisin menaikkan kadar sTfR remaja putri penderita anemia defisiensi besi $(A D B)$ sebelum dikontrol dengan variabel asupan vitamin $C(p=0,01)$ dan sesudah dikontrol asupan vitamin $C(p=0,004)$.
\end{abstract}

Kata kunci: glisin; besi; anemia defisiensi besi; sTfR; Hb; remaja putri

\section{PENDAHULUAN}

Anemia merupakan salah satu masalah gizi utama di seluruh dunia, yang terjadi tidak hanya di negara-negara yang sedang berkembang, tetapi juga di negara maju. Penderita anemia diperkirakan sebanyak dua milyar, dengan prevalensi terbanyak di wilayah Asia dan Afrika. ${ }^{1}$ Kurang lebih sebanyak $50 \%$ anemia disebabkan oleh defisiensi zat besi atau disebut juga dengan Anemia DefisiensiBesi (ADB). ${ }^{2}$

\footnotetext{
${ }^{1}$ IKIP PGRI Semarang
}

Remaja putri merupakan kelompok yang memiliki resiko tinggi terjadinya ADB. Hal ini disebabkan adanya ketidakseimbangan antara asupan zat besi dari makanan dengan kebutuhan zat besi yang meningkat akibat masa pertumbuhan pesat dan menstruasi ${ }^{3}$ Permasalahan ini dapat mengakibatkan terganggunya proses pertumbuhan, menurunkan kecerdasan dan perkembangan mental, menurunkan daya tahan tubuh sehingga rawan infeksi. Anemia menurunkan kualitas remaja putri dalam masa reproduksi untuk mempersiapkan kehamilan dan persalinan kelak $^{4}$ 
Penggunaan sTfR sebagai indikator ketersediaan besi dalam tubuh mempunyai beberapa keuntungan, antara lain tidak dipengaruhi oleh adanya infeksi dan inflamasi, dapat memberikan informasi ketersediaan besi tubuh seperti yang diperoleh dengan pemeriksaan aspirasi sumsum tulang dan hanya membutuhkan sampel serum yang sedikit, selain itu sTfR merupakan indikator yang paling cepat memberikan respon saat suplementasi besi dibandingkan indikator yang biasa dipakai saat ini. ${ }^{9,10,11 .}$

Salah satu upaya yang banyak dilakukan untuk menanggulangi masalah ADB adalah dengan pemberian suplementasi besi oleh karena efektif, murah dan aman, tetapi respon terhadap terapi belum menunjukkan hasil yang optimal2, oleh karena itu, masih perlu dicari pengembangan dari suplementasi besi yang lebih efektif dan efisien, dimana pemberian glisin sebagai tambahan suplementasi besi diharapkan dapat meningkatkan keberhasilan terapi ADB.

Berdasarkan latar belakang tersebut, maka perlu dilakukan penelitian mengenai "Pengaruh suplementasi glisin terhadap kadar serum transferrin receptor (sTfR) dan kadar Hemoglobin $(\mathrm{Hb})$ pada remaja putri ADB yang disuplementasi besi"

\section{BAHAN DAN METODE}

Penelitian ini merupakan penelitian eksperimen semu (quasi experiment) yang menggunakan rancangan pre-post test control group design. Penelitian diawali dengan melakukan skrining pemeriksaan kadar $\mathrm{Hb}$ seluruh remaja putri di panti asuhan putri Ar Rodiyah dan panti asuhan Ikhlasul Amal Semarang yang memenuhi kriteria inklusi yaitu usia 12 - 18 tahun, menderita anemia defisiensi besi yang mempunyai kadar $\mathrm{Hb}<12 \mathrm{mg} / \mathrm{dl}$ dan kadar sTfR $>18,4 \mathrm{nmol} / \mathrm{L}$, bersedia berpartisipasi dengan menandatangani informed consent, dan kriteria eksklusi remaja putri sedang mengalami menstruasi.

Penelitian menggunakan dua kelompok yaitu kelompok perlakuan adalah remaja putri ADB yang mendapat suplementasi besi dan glisin, kelompok kontrol adalah remaja putri $\mathrm{ADB}$ yang mendapat suplementasi besi saja. Penelitian ini menggunakan besi $60 \mathrm{mg}$ pada kelompok kontrol dan besi $60 \mathrm{mg}$ ditambah glisin 1 gram pada kelompok perlakuan. Dosis zat besi ditetapkan $60 \mathrm{mg}$ karena review berbagai studi dengan dosis $60 \mathrm{mg}$ dapat meningkatkan kadar $\mathrm{Hb}$, penelitian oleh Tee et al menunjukkan bahwa penggunaan dosis Fe $60 \mathrm{mg}$ dibanding $120 \mathrm{mg}$ dapat menurunkan keluhan efek samping dan meningkatkan penerimaan suplemen, namun masih memberikan efikasi yang sama terhadap peningkatan $\mathrm{Hb}^{59}$

Dosis glisin 1 gram sesuai dengan dosis harian glisin sehingga diharapkan terjadi perbaikan kadar $\mathrm{Hb}$ dan sTfR pada remaja yang menderita ADB. Pemberian glisin pada suplementasi besi dapat meningkatkan kadar $\mathrm{Hb}$ karena diabsorpsi lebih baik daripada ferrosulfat saja, sehingga ketersediaan hayati (bioavailabilitas) di dalam darah menjadi lebih baik. ${ }^{13}$ Selanjutnya pada remaja putri tersebut dilakukan pengukuran kadar $\mathrm{Hb}$ dan kadar sTfR sebelum dan setelah pemberian suplementasi besi dan glisin pada kelompok perlakuan dan suplementasi besi saja pada kelompok kontrol. Metoda pemeriksaan $\mathrm{Hb}$ dalam penelitian ini menggunakan metode cyanmethemoglobin dikarenakan metode ini lebih canggih dan lebih akurat dibandingkan dengan metode sahli yang masih sederhana. Pemeriksaan sTfR dilakukan dengan metode Enzyme Linked Immunosorbent Assay ( ELISA ) di laboratorium GAKI Universitas Diponegoro Semarang. Tabel 1. Rata-rata kadar $\mathrm{Hb}$ responden.

\section{HASIL}

Tabel 1 menunjukkan bahwa rerata kadar $\mathrm{Hb}$ di awal penelitian lebih rendah dibandingkan dengan rerata di akhir penelitian, hal ini terjadi pada dua kelompok penelitian. Hasil uji paired t- test pada kelompok kontrol dan kelompok perlakuan diperoleh kadar Hb sebelum intervensi (pre test) dengan sesudah intervensi (post test) menunjukkan nilai $\mathrm{p}$ masingmasing $\mathrm{p}=0,037$ dan $\mathrm{p}=0,002$. Hasil ini dapat disimpulkan bahwa ada perbedaan yang signifikan kadar $\mathrm{Hb}$ pada pengukuran awal dan akhir intervensi pada kedua kelompok $(\mathrm{p}<0,05)$.

Tabel 1. Kadar Hb Darah

\begin{tabular}{ccccc}
\hline \multirow{2}{*}{ Kelompok } & \multicolumn{2}{c}{ Kadar Hb darah $(\mathbf{m g} / \mathbf{d l})$} & $\Delta$ & \\
\cline { 2 - 4 } & $\begin{array}{c}\text { Awal } \\
\text { perlakuan }(\boldsymbol{\mu} \pm \mathbf{S D})\end{array}$ & $\begin{array}{c}\text { Akhir perlakuan } \\
(\boldsymbol{\mu} \pm \mathbf{S D})\end{array}$ & $\begin{array}{c}\text { Perubahan selama } \\
\text { 4 minggu }\end{array}$ & $\boldsymbol{p}$ \\
\hline $\begin{array}{c}\text { Perlakuan } \\
(\mathrm{n}=25)\end{array}$ & $10,71 \pm 1,24$ & $11,50 \pm 0,96$ & 0,79 & $0,002^{*}$ \\
\hline $\begin{array}{c}\text { Kontrol } \\
(\mathrm{n}=23)\end{array}$ & $11,27 \pm 0,36$ & $11,50 \pm 0,59$ & 0,22 & $0,037^{*}$ \\
\hline
\end{tabular}


Selisih perubahan rerata kadar $\mathrm{Hb}$ awal dan akhir perlakuan pada kelompok kontrol mengalami peningkatan sebesar $0,22 \mathrm{mg} / \mathrm{dl}$ lebih rendah dibandingkan selisih perubahan rerata kadar $\mathrm{Hb}$ awal dan akhir pada kelompok perlakuan yang mengalami peningkatan sebesar $0,79 \mathrm{mg} / \mathrm{dl}$. Hasil ini menunjukkan bahwa pemberian besi dengan dosis $60 \mathrm{mg}$ maupun besi $60 \mathrm{mg}$ yang ditambah glisin 1 gram selama empat minggu sama - sama memberikan pengaruh dalam meningkatkan kadar $\mathrm{Hb}$ remaja ADB.

Perubahan kadar $\mathrm{Hb}$ pada kelompok perlakuan lebih tinggi dibandingkan kelompok kontrol. Hasil uji statistik menunjukkan $\mathrm{p}=0,002$ sehingga dapat disimpulkan bahwa ada perubahan yang signifikan antara kadar $\mathrm{Hb}$ awal dan akhir. Pemberian suplementasi glisin terbukti memberikan hasil yang signifikan terhadap kenaikan kadar $\mathrm{Hb}$ pada remaja putri yang ADB

Tabel 2 menunjukkan bahwa hasil uji paired $t$ test pada kelompok kontrol didapatkan nilai $\mathrm{p}=0,673$ yang berarti tidak ada perbedaan signifikan rerata kadar sTfR sebelum intervensi (pre test) dengan sesudah intervensi (post test) pada kelompok kontrol $(p>0,05)$.

Hasil uji paired t test pada kelompok perlakuan didapatkan nilai $\mathrm{p}=0,002$. Hasil ini menunjukkan bahwa ada perbedaan yang signifikan kadar sTfR sebelum intervensi (pre test) dengan sesudah intervensi (post test) pada kelompok perlakuan $(\mathrm{p}<0,05)$.

Hasil penelitian ini membuktikan bahwa pemberian suplementasi glisin memberikan hasil yang signifikan terhadap penurunan kadar sTfR pada remaja putri yang ADB. Hasil ini menunjukkan bahwa pemberian glisin dapat meningkatkan bioavailabilitas zat besi. Nilai bioavailabilitas yang tinggi menunjukkan nilai cerna yang tinggi karena adanya aktifitas mikroorganisme yang mendegradasi senyawa makro molekul menjadi bentuk sederhana sehingga mudah dicerna dan diserap.

Tabel 2. Rata- rata kadar sTfR selama penelitian

\begin{tabular}{|c|c|c|c|c|}
\hline \multirow[b]{2}{*}{ Kelompok } & \multicolumn{2}{|c|}{ Kadar $s T f R$ darah $(\mathrm{nmol} / \mathrm{L})$} & \multirow{2}{*}{$\begin{array}{c}\Delta \\
\begin{array}{c}\text { Perubahan selama } \\
4 \text { minggu }\end{array}\end{array}$} & \multirow[b]{2}{*}{$p$} \\
\hline & $\begin{array}{c}\text { Awal } \\
\text { Perlakuan }(\mu \pm S D)\end{array}$ & $\begin{array}{c}\text { Akhir } \\
\text { Perlakuan }(\mu \pm S D)\end{array}$ & & \\
\hline $\begin{array}{l}\text { Perlakuan } \\
(\mathrm{n}=25)\end{array}$ & $\begin{array}{c}35.131,36 \pm \\
17.026,44\end{array}$ & $\begin{array}{c}28.207,76 \pm \\
10.739,51\end{array}$ & $-6.923,60$ & $0,002 *$ \\
\hline $\begin{array}{l}\text { Kontrol } \\
(\mathrm{n}=23)\end{array}$ & $\begin{array}{c}25.131,87 \pm \\
7.889,97\end{array}$ & $\begin{array}{c}25.941,52 \pm \\
5.963 .11\end{array}$ & 809,65 & 0,673 \\
\hline
\end{tabular}

$\Delta$ : selisih rata-rata kadar sTfR akhir perlakuan dan awal perlakuan selama 4 minggu

$p^{*}$ Uji paired t test $(p<0,05)$, signifikan

$\mathrm{p}^{\diamond}$ Uji independent $t$ test $(p<0,05)$, signifikan

\section{PEMBAHASAN}

Glisin dapat dibentuk oleh asam amino treonin dan serin. Glisin dapat diubah kembali menjadi serin pada keadaan lapar. Sintesis hem terjadi melalui serangkaian reaksi biokimia. Reaksi ini terjadi di dalam mitokondria. Bahan utama sintesis hem adalah glisin dan suksinil koenzim A yang berasal dari siklus asam sitrat. Reaksi dimulai dengan kondensasi glisin dan suksinil ko enzim A. Reaksi ini dipacu oleh eritropoetin. Protoporfirin yang terbentuk kemudian berikatan dengan besi ferro membentuk hem. ${ }^{35}$

Setiap molekul hem bergabung dengan rantai globin yang dibuat di poliribosom. Satu tetramer yang terdiri dari empat rantai globin, masing-masing dengan hemnya membentuk satu molekul hemoglobin, seperti yang terlihat pada gambar 1 .

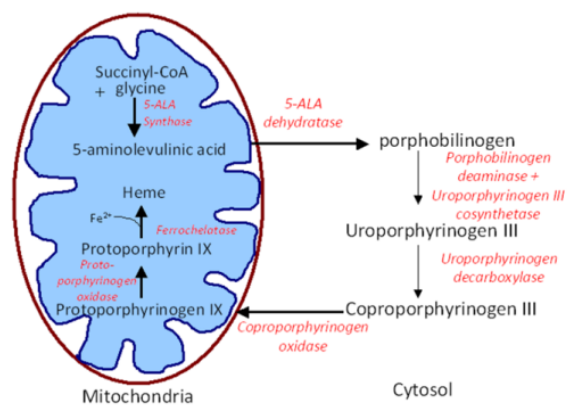

Gambar 1. Sintesis hem oleh glisin ${ }^{32}$ 
Pada penelitian yang dilakukan oleh Bovell Benjamin didapatkan bahwa pemberian $30 \mathrm{mg} / \mathrm{hari}$ preparat iron bisglycine diabsorpsi 4 kali lebih efisien daripada $120 \mathrm{mg}$ ferrosulfat dan didapatkan perbaikan kadar Hb setelah 4 minggu. Penelitian ini menemukan bahwa iron bisglycine memiliki ketersediaan hayati yang lebih baik daripada ferrosulfat dan preparat ini disarankan sebagai fortifikasi diet besi pada kasus anemia dan KEP. ${ }^{13}$ Penelitian oleh Layrisse menunjukkan bahwa dengan pemberian iron bisglycine $37 \mathrm{mg} /$ hari selama 4 minggu pada responden yang minum kopi sebanyak $20 \mathrm{~g} /$ hari atau teh sebanyak 20 $\mathrm{g} /$ hari, menunjukkan bahwa terdapat perbaikan kadar $\mathrm{Hb}$ pada kelompok yang diberi iron bisglycine dibandingkan kelompok yang hanya diberikan ferrosulfat saja, ${ }^{47}$ sehingga dapat dikatakan dengan pemberian ironbisglycine dapat mencegah efek buruk fitat dan polifenol yang berpotensi mengganggu penyerapan besi. Penelitian suplementasi besi yang diberikan bersamaan dengan pemberian glisin yang dilakukan oleh Jin pada anak yang anemia selama 4 minggu menunjukkan terjadinya peningkatan kadar $\mathrm{Hb}$ dan FEP dibandingkan jika diberikan besi saja. ${ }^{48}$ Hasil yang sama juga didapatkan pada penelitian oleh Santos, bahwa dengan suplementasi besi yang diberikan bersamaan dengan pemberian glisin pada anak yang anemia menunjukkan peningkatan kadar $\mathrm{Hb} 1,1 \mathrm{~g} / \mathrm{dl}$ dan peningkatan plasma ferritin $12,4 \mu \mathrm{g} / \mathrm{ml}$ dibandingkan yang hanya diberikan suplementasi besi saja peningkatan kadar $\mathrm{Hb} 0,9 \mathrm{~g} / \mathrm{dl}$ dan peningkatan plasma ferritin $5,6 \mu \mathrm{g} / \mathrm{ml}^{49}$

Pada penelitian ini, Selisih perubahan kadar $\mathrm{Hb}$ awal dan akhir perlakuan pada kelompok kontrol mengalami peningkatan sebesar $0,22 \pm 0,48 \mathrm{mg} / \mathrm{dl}$ lebih rendah dibandingkan rerata perubahan kadar $\mathrm{Hb}$ awal dan akhir pada kelompok perlakuan yang mengalami peningkatan sebesar $0,79 \pm 1,15 \mathrm{mg} / \mathrm{dl}$. Hasil uji statistik antara kedua kelompok yang memiliki varian sama menggunakan uji independen $\mathrm{t}$ test menunjukkan nilai $\mathrm{p}=0,03$. Hasil ini menunjukkan adanya selisih perubahan kadar Hb yang bermakna antara kelompok kontrol dengan kelompok perlakuan ( $p<0,05)$. Hasil ini seperti hasil penelitian Jin YS dan Pineda, bahwa terjadi peningkatan kadar $\mathrm{Hb}$ yang bermakna pada kelompok yang diberi besi glisin chelate dibanding kelompok yang hanya diberi ferro sulfat.

Pemberian suplementasi glisin terbukti memberikan hasil yang signifikan terhadap kenaikan kadar $\mathrm{Hb}$ pada remaja putri yang $\mathrm{ADB}$, hasil penelitian ini sejalan dengan hasil penelitian Jin YS dan Pineda, bahwa pemberian suplementasi besi glisin chelate meningkatkan kadar $\mathrm{Hb}$, plasma ferritin serta menurunkan FEP. ${ }^{48}$

Hasil penelitian ini membuktikan bahwa pemberian suplementasi glisin memberikan hasil yang signifikan terhadap penurunan kadar sTfR pada remaja putri yang ADB. Hasil ini menunjukkan bahwa pemberian glisin dapat meningkatkan bioavailabilitas zat besi. Nilai bioavailabilitas yang tinggi menunjukkan nilai cerna yang tinggi karena adanya aktifitas mikroorganisme yang mendegradasi senyawa makro molekul menjadi bentuk sederhana sehingga mudah dicerna dan diserap. Hal ini sesuai dengan Beberapa penelitian sebelumnya yang menunjukkan bahwa preparat iron bisglycine chelate yaitu senyawa besi glisin chelate dapat menghasilkan konfigurasi cincin heterosiklik ganda yang dapat melindungi besi dari faktor penghambat besi dan berbagai interaksi di usus halus, sehingga preparat ini memiliki ketersediaan hayati dua kali lebih tinggi dibandingkan dengan ferrosulfat. ${ }^{14}$ Glisin merupakan asam amino yang terlibat dalam biosintesis $\mathrm{Hb}$. Hb membentuk sekitar 95 $\%$ dari protein intrasel pada eritrosit, sehingga pemberian glisin dapat membantu proses produksi eritrosit. Glisin juga membentuk antioksidan glutation yang dapat mempertahankan besi diet dalam bentuk ferro, sehingga absorpsi besi dapat ditingkatkan dan ketersediaan hayati besi dalam tubuh dapat ditingkatkan.

\section{SIMPULAN}

Berdasarkan hasil penelitian ini dapat disimpulkan bahwa pemberian suplementasi glisin dapat menurunkan kadar sTfR pada remaja putri anemia defisiensi besi yang disuplementasi besi, dan suplementasi glisin dapat meningkatkan kadar $\mathrm{Hb}$ pada remaja putri anemia defisiensi besi yang disuplementasi besi.

\section{DAFTAR PUSTAKA}

1. McLean E. Worldwide prevalence of anemia 1993 - 2005. WHO global database on anemia, 2008. Available from:

http://www.who.int/nutrition/publications/micron utrients/phnmay2008.pdf.

2. WHO/UNICEF/UNU. World prevalence of anemia. Geneva, WHO report 2008. Available from:

http://www.who.int/nut/documents/ida_assessme nt prevention control.pdf.

3. IKG Suandi. Gizi pada masa remaja. Dalam: Soetjiningsih, penyunting. Buku ajar tumbuh kembang remaja dan permasalahannya. Jakarta: Sagung Seto, 2004. Hal 23-8.

4. Alton I. Iron Deficiency Anemia. In: Stang J, Story M. Guidelines for Adollessent Nutrition Services, 2005. $101-8$.

5. DeMayer EM, Tegman A. Prevalence of anemia in the world. WHO qlty 2003; 38: $302-16$. 
6. Azwar A. Kecenderungan masalah gizi dan tantangan di masa mendatang. Pertemuan Advokasi Program Perbaikan Gizi Menuju Keluarga Sadar Gizi; 27 September 2004; Jakarta, Indonesia.

7. Dinas Kesehatan Kota Semarang. Profil Kesehatan Kota Semarang Tahun 2008, 2008. Semarang: Dinas Kesehatan Kota Semarang.

8. Tong EM, Nissenson AR. Erythropoetin and anemia. Semin Nephrol. 2001; 21:190-203.

Goddard AF, James MW. Guidelines for the management of iron deficiency anaemia. 2005. Available from: http://www.bsg.org.uk/clinicalguidelines/small-bowel-nutrition/guidelines-forthe-management-of-iron-deficiency-anaemia2005.html

9. Cook J. Diagnosis and management of irondeficiency anaemia. Best Pract Res Clin Haematol. 2005;18(2):319-22.

10. Brandao $\mathrm{M}$. The soluble transferrin receptor as a marker of iron homeostatis in normal subjects and in HFE related hemochromatosis. Haematologica 2005; 90(I):31-37.

11. Gersten D. About Amino Acids. 2002. Available from:

http://www.aminoacidpower.com/aboutamino/a minotour20.

12. Bovell-Benjamin AC. Iron absorption from ferrous bisglycinate and ferric triglycinate in whole maize is regulated by iron status. Am $\mathrm{J}$ clin Nutr 2000; 71:1563-9.

13. Olivares M. Milk inhibits and ascorbic acid fevors ferrous bis-glycine chelate bioavailability in humans. Am J Nutr 2000; 71:1563-9.

14. Arisman. Gizi dalam daur kehidupan. Penerbit buku kedokteran EGC. 2002:15-20.

15. WebMD. Understanding anemia the basics. 20052013. Available from:

http://www.webmd.com/a-to-zguides/understanding-anemia-basics.

16. Beard JL. Iron requirements in adolescent female. $2000 . \quad$ Available from: http://www.ncbi.nlm.nih.gov/pubmed/10721923.

17. Bakta IM. Hematologi Klinik ringkas. Percetakan Universitas Udayana Denpasar. 2000:34-36.

18. Kodyat BA. NHS. Masalah gizi masyarakat dan program penanggulangannya.Dalam: Samsudin, Nasa SR, Syarif DR. Edisi naskah lengkap pendidikan kedokteran berkelanjutan ilmu kesehatan anak: masalah gizi ganda dan tumbuh kembang anak. Binarupa Aksara. Jakarta. 2005:54-69.

19. Almatsier. Prinsip dasar ilmu gizi. Gramedia Pustaka Utama. Jakarta. 2001: 81-82.
20. Luh SA. Metabolisme zat besi pada tubuh manusia. Widya Biologi Vol 02 No 01 Maret 2011. ISSN: 2086-5783.

21. Nair KM, Iyengar V. Iron content, bioavailability and factors affecting iron status of Indians. Indian J Med Res. 2009:634-45.

22. Kuntarti. Air, $\mathrm{pH}$, dan mineral. Available from: www.stafui.ac.id

23. Muhammad A, Sianipar O. Penentuan defisiensi anemia menggunakan peran indeks sTfR-F. Telaah Pustaka. Available from: http://www.journal.unair.ac.id

24. Ghosh K. The non hematologic effects of iron deficiency. Indian J Med Res. 2006;60(1):315 22.

25. Institute of Health Management - Pachod (IHMP) and International Center for Research on Women (ICRW). Reducing anemia and changing dietary behaviors among adolescent girls in Maharashtra, India. 2004. Available from: http://www.icrw.org/docs/2004indiareprohealth8. pdf

26. Hoffman R. Iron metabolism basic principle and practice $3^{\text {rd }}$ ed, Churchill livingstone, 2000:39945.

27. Bambang S. Soluble transferrin receptor. Dalam: Syamsul A, IPG Ugrasena, Alpha F, eds. Comprehensive management in children with hematology oncology problem. 2009:55-56.

28. Chang Y, Zak O, Aisen P. Structure of the human transferrin receptor-transferrin complex. Cell press. 2004;116(4):565-76.

29. Hertanto WS. Hubungan antara status vitamin A dan seng pada ibu hamil dengan keberhasilan suplementasi besi. Disertasi. Universitas Diponegoro Semarang. 2002:21-22.

30. Murray KR, Granner KD, Mayer AP, Rodwell WV. Biokimia Harper. Alih bahasa: Hartanto Andy. Edisi 27. Jakarta: Buku Kedokteran EGC; 2009 :299-302.

31. Berg MA. Campbell biology $8^{\text {th }}$ edition. A heme oxygenase product. 2014. Available from: http://www.sicke.bwh.harvard.edu/hemoglobino pathy.html.

32. Marengo AJ. Structure function relations of human hemoglobins. 2006;19(3). Available from: http://www.ncbi.nlm.nih.gov.

33. Hoffbrand AV, Petit JE. Essential hematology. $6^{\text {th }}$ edition. Carlton: Blackwell scientific publications. 2011:243-45.

34. Tyson nutraceuticals. Whatis glycine. Aatron medical services. Scientific division of Tyson nutraceutical. 2008. Available from: http://www.tysonnutraceutical.com/glycine02.ht m. 
35. Gibson NR, Jahoor F, Ware L, Jackson AA. Endogenous glycine and tyrosine production is maintened in adult consuming a marginal protein diet. Am J Clin Nutr. 2002. 75:511-18.

36. Christie GR, Ford D, Howard A. Glycine supply to human enterocytesmediated by high affinity basolateral GLY1. Gastroenterol J. 2001; 120:439-48.

37. Cinzia L, Marconi AM, Ronzoni S. Placental transport of leucine, glycine, and proline in intrauterine growth. Journal of clinical endocrinology and metabolism. 2001;86(11):5427-32.

38. Gannon MC, Nuttal JA. The metabolik response to ingested glycine. American society for clinical nutrition. 2002;76(6):1302-7.Andrews NC, Roy CN. Recent advance in disorders of iron metabolism. Hum mol genet. 2001;10(20):21816.

39. Depkes RI. Pedoman Pemberian Tablet Besi, Folat dan Sirup Besi Bagi Petugas. Jakarta: Direktorat Jendral Pembinaan Kesehatan Masyarakat Direktorat Bina Gizi Masyarakat;2003:12-16.

40. Murray KR, Granner KD, Mayer AP, Rodwell WV. Biokimia Harper. Alih Bahasa: Hartanto Andy. Edisi 24. Jakarta: Buku Kedokteran EGC; $1996: 299-302$.

41. Cook JD, et al. Effect of ascorbic acid intake on non heme iron absorption from a complete diet. Am J Clin Nutr. 2001; 73(1): p.93-8.

42. Hallberg L, Walczyk T, Davidsson L, Hurrel RF. No enhancing effect of vitamin A on iron absorption in humans. Am J Clin Nutr. 2003; 77(1): p.144-9.

43. Zimmermann MB. Vitamin A supplementation in children with poor vitamin $\mathrm{A}$ and iron status increases erythropoetin and hemoglobin concentrations without changing total body iron. Am J Clin Nutr. 2006; 84(3): p.580-6.

44. Ahmed F. Efficacy of twice-weekly multiple micronutrient supplementation for improving the hemoglobin and micronutrient status of anemic adolescent schoolgirls in Bangladesh. Am J Clin Nutr. 2005;82(4): p.829-35.

45. Miguel L, Solano L, Llovera D, Baron A. Iron bioavailability in humans from breakfast enriched with iron bis glycine chelate, phytates, and polyphenols. J Nutr. 2000; 130(9): p.2195-9.

46. Jin YS. Evaluation on glycine chelate iron (II) in improving nutritional anemic children. Journal of hygiene research. 2005; 34(3):p.344-6.

47. Santos DMM. Effectiveness of different intervention strategies with iron in Hemoglobin and ferritin concentrations in children in Piaui, Brazil. 2007; 23(7):1547-52.
48. Lemeshow S, David WH Jr, Klar J, Lwanga SK. Besar sampel dalam penelitian kesehatan (terjemahan). Alih bahasa: Pramono, Dibyo, dan Hari K. Gajahmada Univercity Press. Yogyakarta. 1997.

49. Sakti H, Rachmawati B, Rahfiludin MZ. Pengaruh suplementasi tablet besi dan pendidikan gizi terhadap pengetahuan, sikap, praktek tentang anemi dan kadar hemoglobin $(\mathrm{Hb})$ pada remaja putri. Media Medika Indonesiana. Fakultas Kedokteran Universitas Diponegoro Semarang. 38(1):24-30.

50. Fikawati S, Syafiq A, Nurjuaida S. Pengaruh suplementasi besi satu dan dua kali per minggu terhadap kadar hemoglobin pada siswi yang menderita anemia. Universa Mediciana. Lintas departemen kesehatan Fakultas Kesehatan Masyarakat Universitas Indonesia. Jakarta. Vol 24 no 4.

51. Thurlow et al. Only a small proportion of anemia I northeast thai schoolchildren is associated with iron deficiency. Am J clin nutr. 2005; 82: p.385.

52. Yip R. The challenge of improving iron nutrition. European Journal of clinical nutrition. 1998; 95:2225.

53. Farida I. Determinan kejadian anemia pada remaja putri di kecamatan gebog kabupaten kudus tahun 2006. Tesis. Universitas Diponegoro Semarang. 2007:54 - 55.

54. Teti K. Hubungan asupan energi dan zat gizi terhadap kejadian anemia pada remaja putri di SMAN 2 Moncong. Universitas Hasanudin. 2012.

55. Depkes RI. Riset Kesehatan Dasar 2010. Jakarta. 2010.

56. Kirana DP. Hubungan asupan zat gizi dan pola menstruasi terhadap kejadian anemia di SMAN 2 Semarang. Fakultas Kedokteran Universitas Diponegoro Semarang. 2011.

57. Tee E, et al. School administrated weekly iron sulfate supplements improve hemoglobin and ferritin concentrations in Malaysian adolescent girls. Am J Clin Nutr. 1999; 69:1249-56. 